\title{
IPO in the countries of the Gulf Cooperation Council
}

\begin{abstract}
The Arab States of the Gulf Cooperation Council (GCC) host one of the fastest developing, yet one of the most closed groups of securities markets in the EMEA region. This study provides an analysis of the regional securities market and compares it with global securities' market trends for the period 2000 to 2014 . The study refers to regional IPO activity as a reflection of the level of maturity of the local economy. An IPO Market Ratio is introduced in this study as an instrument for measuring the national economy so as to be able to further compare it to other economies. The study provides descriptions of the financial markets of all GCC economies, outlines their developmental history, and develops a ranking of GCC countries based upon weighted normalized IPO Market Ratio data. The collected information and the results of the analysis are presented both in table and graphical formats.
\end{abstract}

Keywords

GCC $\cdot$ regional stock exchange $\cdot$ GCC IPO market $•$ IPO $•$ IPO market ratio (C) University of Warsaw - Faculty of Geography and Regional Studies
Aidrous Irina Ahmed Zein'1, Sofya Glavina Grigorievna²

${ }^{1}$ The Institute of International Economics and Business People's Friendship University of Russia, Russia e-mail: aidrous@mail.ru

${ }^{2}$ The Institute of International Economics and Business, People's Friendship University of Russia, Russia e-mail: sofya.glavina@gmail.com

Received: 17 December 2015

Accepted: 16 June 2016
Introduction

Initial Public Offering (IPO) is a well-known way of raising capital by issuing a company's securities. The level of development of a national stock market and its potential for growth are characterized by a company's aspiration to make a public offering on this market, and the stock market's ability to attract investors. Stock markets of the GCC region provide a good example of a developing regional market with a good potential for investment. At the same time the GCC's financial market is, to a great extent, not transparent and its potential has not been well studied and, therefore, not accurately estimated by the international investment community.

The purpose of this study is to describe the key trends in the GCC's IPO market and to reflect the attractiveness of the region for foreign capital. Activity on the IPO market is an indicator of the level of maturity of the local regulations that provide a comfortable business environment and terms for investors. The analysis of IPO activity in the GCC region covers visible activity on the financial market since the beginning of the century.

The scarce few studies that have been done on Middle East financial markets have been conducted on either individual stock markets (Erb et al. 1996) or on sets of markets within the MENA region (Abraham et al. 2001). Omar and Gunduz (2001) analysed various MENA market subsets but couldn't find any inter-linkages despite the markets' geographic proximity. The most popular studies on IPO markets cover the problem of underpricing. Abdullah Al-Hassan and Fernando Delgado (2007) investigated IPO underpricing for fortyseven firms from the GCC who went public between 2001 and 2006. This paper supports the hypothesis that investors initially tend to be over-optimistic about the performance of IPOs, but grow more pessimistic over time. The study of the financial and operating performance of fifty-two IPOs undertaken in the GCC region between 2003 and 2010 indicates that the performance declined after companies went public (Ahmed S et al. 2013). This performance is associated with the firm's transition from private to the public ownership and is due to increasing agency costs. Studies of the relations between the stock market and oil price are also presented in IPO studies (Harrathi and Almohaimeed 2015).

The current study is based on the analysis of regional information that was collected from various sources. This paper refers to data sourced from stock exchange reports and papers by respectable audit and consulting companies such as Ernst \& Young (E \& Y 2012; 2013; 2015) and PricewaterhouseCoopers (PwC 2010; 2011; 2012; 2013; 2014; 2015). ABQ Zawya and Gulf Base were used as additional sources of information since they provide comprehensive information about the regional stock market, stock trading volumes and prices. The authors also used a report by the Institute of International Risks (Gokkent et al. 2014), which provides a basic description of regional economies and focuses on the financial system and stock markets particularly. The IPO efficiency index, which measures the share of the IPO value to GDP of the country, was also used. Data and the results of analysis are presented in graphical and table formats in this paper.

The data for quantitative analysis is taken from several sources and the qualitative method is used to interpret the different characteristics and dependencies. Furthermore, the comparative analysis is used to indicate the dependencies and influences on the regional IPO market. 
The first part of the study is dedicated to the GCC region's economic development, outlines its key characteristics and covers the general aspects of stock market development of GCC countries. It is followed by a description of the special aspects of IPOs in GCC countries and the results of the influence of the global economy, as well as defining the dependencies of global IPO market trends. The final part covers a separate basic description of the development of the IPO market and stock market for each of six countries. Finally, the method for comparing IPO market activity is introduced and applied to GCC markets.

\section{Special aspects of IPOs in GCC countries}

Despite the fact that the economies of GCC countries are historically hydrocarbon based, it has to be mentioned that the non-hydrocarbon sectors of economy shows higher growth rates than the traditional energy sector. (Gukasyan 2010). The total economic growth for GCC countries during the period 20112013 , varied from $4.2 \%$ to $6.9 \%$. It is also worth mentioning that the world financial crisis had no dramatic impact on the GDP of the GCC countries, and figures for the GCC region follow the general trend of world GDP. (Figure 1). Since the economy of GCC countries is greatly influenced by oil prices and oil production volume, which in turn depends on the global economy and external political factors, the fraction of GDP that is not associated with the hydrocarbon sector of the economy could become an indicator of countries core economic mechanisms and potential for development.

International IPO market activity depends on the world capital market, which has not completely recovered from the global financial crisis of 2008-2009. Low stability in the Eurozone, pessimistic prospects for the recovery of the world economy, and a slowdown in China's economic growth as well as a long period of market volatility has caused a decrease in activity on the current IPO market. The IPO market in GCC countries is much smaller when compared to the world key financial markets. GCC countries accounted for nine public offerings in 2013 compared to 238 in the USA, 279 in Europe and 144 in China for the same period of time (PwC 2010). Despite the small size of the GCC IPO market it follows the general trends of the global IPO market slow growth rates in the first decade of the 2000 s, partly because both local investors and local companies had little trust or experience in raising capital through IPOs. The maximum number of IPOs on the stock markets of GCC countries was carried out in 2007 with thirty-four deals, which raised a total of USD 11.99 billion. (Figure 2). The world financial crisis of 2008-2009 made a negative impact on the economic climate of the GCC region. The GCC's IPO market activity significantly decreased in Q4 of 2008 due to instability in the global financial market during 2008-2009, the downturn in oil prices, the withdrawal of capital from the GCC's financial market by institutional investment funds and an overheated local real estate market (PwC 2012). Even in Saudi Arabia, the most active market player, IPO activity slowed down. In a response to the crisis some companies operating in the GCC region preferred to delay their planned IPOs until better times, or even to cancel them. Investors also switched their focus from emerging markets to more reliable and mature markets like London and New York. Cases of insider trading, which had become known to the public, and flaws in legislation slowed down IPO activity in the region. The GCC countries responded by tightening regulations and raising the formal requirements for IPO candidates, leading to a growing interest in the IPO market in the region. The slowdown of the IPO market in the GCC region also continued in 2011, which could also be called the year of "Islamic finance": several GCC based companies turned to an alternative source of financing, namely sukuk - Islamic securities (PwC 2012). Since the global financial crisis, 2014 has proved to

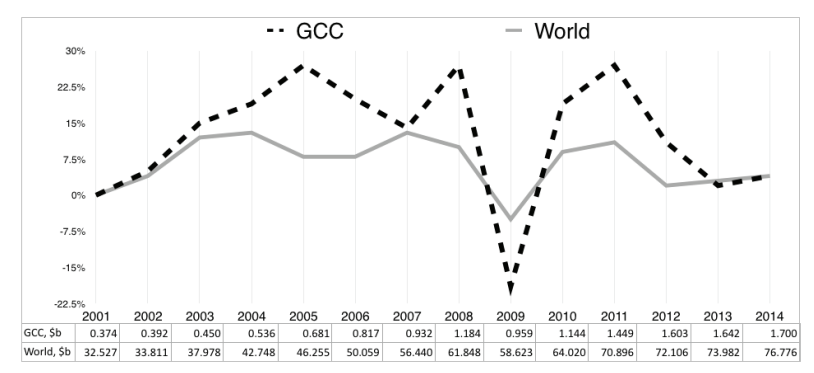

Source: prepared by the authors using International Monetary Fund data

Figure 1. Nominal GDP growth for the world and the GCC countries, 2001-2014 (in billions of USD and \%)

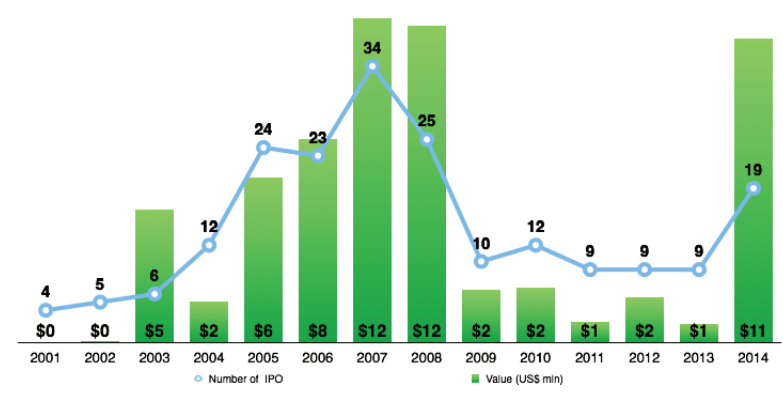

Source: prepared by the authors using PwC (2010; 2011; 2012; 2013; 2014; 2015)

Figure 2. IPO market of GCC countries 2001-2014.

be the busiest year in the region's equity capital markets. By far the most active securities exchange has been Saudi Arabia's Tadawul, which demonstrated a number of new listings in 2014, lead by the enormous IPO of the National Commercial Bank (Tarbuck et el. 2014). The first quarter of 2015 showed a dampening of optimism and a lower IPO appetite for the GCC countries as a result of a decreasing trend in oil price that became obvious at the end of 2014 (PwC 2015). Oil is one of the key drivers of economic growth in the countries of the GCC, and the impact of the slump in oil prices has proved to be significant in the region's economy and IPO market. The initial demand anticipated for IPOs was short lived following the drop in oil prices, which caused volatility in the market and left investors feeling at risk and putting on hold any plans for investments. Some GCC based companies preferred to offer their securities on global IPO markets. The London stock market took $59 \%$ of the GCC countries' international placements, while Singapore took $24 \%$, followed by New York with 14\%, and Hong-Kong with 3\% (Deloitte 2013). The popularity of the London stock market among GCC companies can be explained by its high reputation as the leading financial centre, high liquidity, openness to different schemes of stock placement, and its high qualification of risk assessment. IPOs in the GCC region were mainly carried out by companies in telecommunication, real estate, finance and commercial services industries (Gokkent et el. 2014). This can be explained by the fact that the hydrocarbon sector in the GCC region is mature and its key business players are already represented on the stock market, or occupy a comfortable market niche, thus paving the way for the development of other industries.

The ratio between the IPO value and the GDP of a selected country reflects the ability of the local economy to either create favourable conditions for local businesses or to attract capital. The 
MISCELLANEA GEOGRAPHICA - REGIONAL STUDIES ON DEVELOPMENT

Vol. $20 \cdot$ No. $3 \cdot 2016 \cdot$ pp. 32-36 • ISSN: 2084-6118 • DOI: 10.1515/mgrsd-2016-0017

Table 1. GCC's IPO market activity 2001-2014 on Normalized IPO Market Ratio.

\begin{tabular}{|c|c|c|c|c|c|c|c|c|c|c|c|c|c|c|c|c|c|c|c|c|c|c|c|}
\hline & & Bahro & & & Kuwa & & & Qata & & & Omar & & & audi Ara & ibia & & UAE & & & & Total & & \\
\hline & 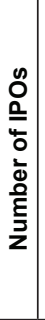 & 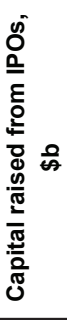 & 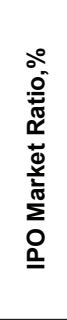 & 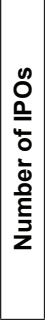 & 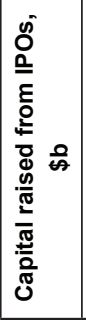 & 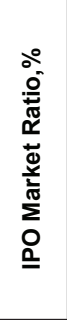 & 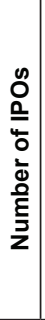 & 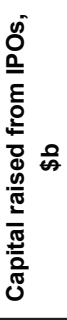 & 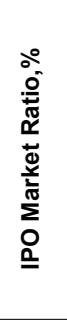 & 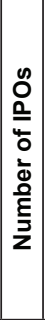 & 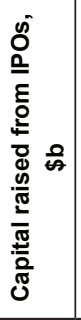 & 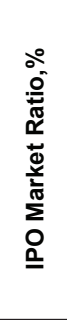 & 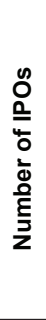 & 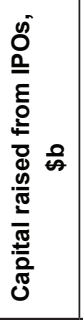 & 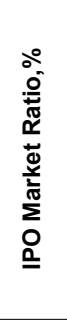 & 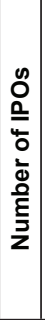 & 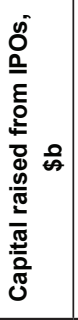 & 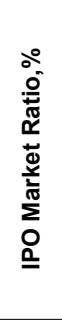 & 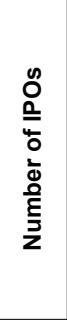 & 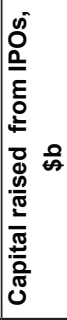 & $\begin{array}{l}0 \\
\text { A } \\
0 \\
0 \\
0\end{array}$ & 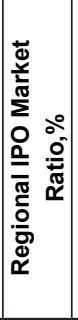 & 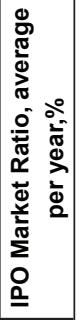 \\
\hline 2001 & & & & & & & & & & 4 & 0.03 & 0.16 & & & & & & & 4 & 0.0 & 391.8 & 0.01 & 0.03 \\
\hline 2002 & & & & & & & 2 & 0.06 & 0.29 & 2 & 0.02 & 0.08 & & & & 1 & 0 & & 5 & 0.1 & 449.8 & 0.02 & 0.06 \\
\hline 2003 & & & & 2 & 0.08 & 0.17 & 3 & 0.76 & 3.21 & & & & 1 & 4.08 & 1.84 & & & & 6 & 4.9 & 535.6 & 1.09 & 0.87 \\
\hline 2004 & & & & 4 & 0.74 & 1.25 & & & & 2 & 0.04 & 0.16 & 2 & 0.35 & 0.13 & 4 & 0.38 & 0.26 & 12 & 1.5 & 681.3 & 0.28 & 0.30 \\
\hline 2005 & 3 & 0.1 & 0.63 & 2 & 0.22 & 0.27 & & 1.11 & 2.49 & 4 & 0.82 & 2.64 & 5 & 2.05 & 0.62 & 7 & 1.80 & 0.99 & 21 & 6.1 & 816.6 & 0.89 & 1.27 \\
\hline 2006 & 3 & 1.04 & 5.61 & 2 & 0.12 & 0.12 & 3 & 1.32 & 2.16 & 2 & 0.05 & 0.15 & 10 & 3.18 & 0.84 & 3 & 1.80 & 0.81 & 23 & 7.5 & 931.9 & 0.92 & 1.61 \\
\hline 2007 & 1 & 0.07 & 0.32 & & & & 3 & 0.39 & 0.49 & 1 & 0.16 & 0.37 & 26 & 4.81 & 1.16 & 4 & 6.56 & 2.54 & 35 & 12.0 & 1080.6 & 1.29 & 0.81 \\
\hline 2008 & & & & 1 & 0.10 & 0.07 & 2 & 0.51 & 4.45 & 2 & 0.07 & 0.12 & 13 & 9.75 & 1.88 & 8 & 1.27 & 0.40 & 26 & 11.7 & 958.8 & 1.08 & 1.15 \\
\hline 2009 & & & & & & & 1 & 0.95 & 0.97 & & & & 9 & 1.00 & 0.23 & & & & 10 & 2.0 & 1143.8 & 0.20 & 0.20 \\
\hline 2010 & 1 & 0.48 & 2 & & & & 1 & 0.04 & 0.03 & 1 & 0.27 & 0.46 & 9 & 1.25 & 0.24 & & & & 12 & 2.0 & 1449.3 & 0.18 & 0.43 \\
\hline 2011 & & & & & & & 1 & & & 1 & 0.06 & 0.09 & 5 & 0.46 & 0.07 & 3 & 0.27 & 0.08 & 10 & 0.8 & 1603.3 & 0.05 & 0.04 \\
\hline 2012 & & & & & & & & & & 2 & 0.26 & 0.34 & 7 & 1.42 & 0.19 & & & & 9 & 1.7 & 1642.2 & 0.10 & 0.09 \\
\hline 2013 & & & & & & & & & & 4 & 0.18 & 0.22 & 5 & 0.52 & 0.07 & & & & 9 & 0.7 & 1648.1 & 0.04 & 0.05 \\
\hline 2014 & & & & 1 & 0.09 & 0.05 & 2 & 0.98 & 0.47 & 4 & 1.85 & 2.38 & 6 & 6.73 & 0.89 & 6 & 1.6 & 0.40 & 19 & 11.3 & 13706.8 & 0.68 & 0.70 \\
\hline \multirow{5}{*}{ Total } & 8 & 1.68 & 0.56 & 12 & 1.35 & 0.09 & 18 & 6.11 & 0.47 & 29 & 3.81 & 0.57 & 98 & 35.61 & 0.56 & 36 & 13.68 & 0.39 & 201 & 62.2 & 13706.8 & 0.45 & 0.44 \\
\hline & \multicolumn{3}{|c|}{0.210} & \multicolumn{3}{|c|}{0.112} & \multicolumn{3}{|c|}{0.339} & \multicolumn{3}{|c|}{0.131} & \multicolumn{3}{|c|}{0.363} & \multicolumn{3}{|c|}{0.379} & 0.309 & \multicolumn{4}{|c|}{$\begin{array}{c}\text { Single IPO average value, } \\
\$ b\end{array}$} \\
\hline & \multicolumn{3}{|c|}{0.56} & \multicolumn{3}{|c|}{0.09} & \multicolumn{3}{|c|}{0.47} & \multicolumn{3}{|c|}{0.57} & \multicolumn{3}{|c|}{0.56} & \multicolumn{3}{|c|}{0.39} & 0.45 & \multicolumn{4}{|c|}{ IPO Market Ratio, \% } \\
\hline & \multicolumn{3}{|c|}{0.6} & \multicolumn{3}{|c|}{0.14} & \multicolumn{3}{|c|}{1.04} & \multicolumn{3}{|c|}{0.51} & \multicolumn{3}{|c|}{0.58} & \multicolumn{3}{|c|}{0.39} & 0.48 & \multicolumn{4}{|c|}{$\begin{array}{c}\text { Average IPO Market Ratio, } \\
\%\end{array}$} \\
\hline & \multicolumn{3}{|c|}{12.5} & \multicolumn{3}{|c|}{6} & \multicolumn{3}{|c|}{26.5} & \multicolumn{3}{|c|}{28} & \multicolumn{3}{|c|}{17.5} & & 9.5 & & & & $\begin{array}{r}\text { rmalized IF } \\
\text { Ratio, }\end{array}$ & $\begin{array}{l}\mathrm{PO} \mathrm{Mar} \\
, \%\end{array}$ & \\
\hline
\end{tabular}

Source: prepared by the authors using PwC (2010; 2011; 2012; 2013; 2014; 2015), E \& Y (2011; 2012)

IPO Market Ratio can be used to compare IPO markets in different counties regardless of the size of its economy (represented by national GDP). It could also be helpful in monitoring IPO activity in a particular country, or group of counties, over a period of time, as well as for comparing the markets of countries developing in similar conditions. The highest values of IPO Market Ratio, worldwide, for the period from 2001 to 2014 have been observed in fast growing economies: Singapore $(9.7 \%)$, Malaysia $(6.4 \%)$ and China (2.9\%) (Gokkent et el. 2014). Mature economies provide significantly lower figures of IPO Market Ratio due to a larger base for the GDP generating economy. On average, the IPO Market Ratio in the GCC region for the period from 2001 to 2014 was close to $0.4 \%$, achieving a maximum value of $2 \%$ in 2009 (Table 1). It is fair to say that the hydrocarbon sector of the economy is responsible for a big share of GDP in the GCC region thus lowering IPO Market Ratio figures.

The visible progress in the GCC stock market's development, beginning in 2001, was the result of the continuous adoption of international standards and principles of stock exchange operation. September 11, 2001 became a turning point that initiated close inspection of the capital in financial markets for possible connections to terrorist organizations. A lot of investors from the GCC region who formerly invested billions in Western financial markets turned to local projects and funds (Birukov 2012). The high level of oil prices and the increase in oil production during the studied period also helped the regional economy to accumulate significant resources for further investment, and also encouraged the local population to participate in the process of investment.

The GCC Financial market shows a high level of profitability when compared with global markets. Despite this high level of profitability, the GCC financial market has a serious weak point in that it does not provide sufficient information to investors, which often leads to high market volatility. This lack of information could often be the reason for incorrect assumptions made by investors due to an overestimation of some of its industries or the whole 
market itself. A market price surge on certain stocks and a growing gap between its stock market price and supported prices could only indicate a growing bubble on the GCC stock market (Birukov 2011).

\section{IPO market trends in three GCC regions}

There has been 192 IPOs in the GCC region, with a total value of USD 52.8 billion in the period 2001-2014. The Kingdom of Saudi Arabia is the absolute leader in the IPO market for the GCC region and is responsible for roughly half of all IPOs, mainly due to the large share its economy has in the region (Table 1). At the same time it is a closed market - the local stock market is accessible only for GCC region players, so foreign investors can get access to this market only through the mechanism of portfolio investments. (Birukov 2012). Unlike Saudi Arabia, foreign investors in Qatar are permitted to buy stocks traded on the local stock market, but in volumes less than $25 \%$ of the particular security (Birukov 2011). However, foreign companies are not allowed to offer their securities on the local stock exchange, leaving this privilege to local and GCC based companies. The United Arab Emirates hosts three stock exchanges: Abu Dhabi Securities Exchange (ADX), Dubai Financial Market (DFM), and Nasdaq Dubai, which is located in the free trade zone of Dubai International Financial Centre. The current stock market slowdown raised the issue of merging together the ADX, DFM and NASDAQ Dubai UAE stock exchanges, with the aim of creating a competitive and transparent stock market, an increased quality of corporate management, and investor protection. Kuwait hosts the oldest stock exchange within the GCC region - the Kuwait Stock Exchange (KSE). Historically, speculative trade practices and a failure to follow the stock market's own regulations for companies that went public, made a negative impact on the KSE's image causing market crashes in 1976 and 1982 (Chalhoub 2010). Since then the Kuwaiti government has made several reforms with the aim of increasing the KSE's effectiveness. Accusations of insider trading and market manipulation recently provided another blow to KSE's reputation (Chalhoub 2010). The IPO market in Kuwait is the smallest stock exchange in the region rated on attracted capital. The stock exchange of the Sultanate of Oman, the Muscat Securities Market (MSM), is the most open stock market for international capital when compared with the other GCC stock exchanges and foreign investors are allowed to buy stocks in Oman based companies. The Kingdom of Bahrain is the key financial centre of the region. In 2010 the Central Bank of Bahrain (CBB) revised stock exchange regulatory terms that were concerned with disciplinary action and the settlement of disputes. These measures were taken in view of regaining trust in the BSE that had eroded during the financial crisis, and which had decreased the capitalization of the stock market more than twice (Chalhoub 2010). Bahrain has the lowest IPO activity among the GCC stock exchanges.

Earlier in this study the IPO Market Ratio was used as a tool to measure a country's ability to accommodate IPOs. This metric proves to be helpful in comparing economies of the same calibre, over the same period of time. The IPO Market Ratio figures calculated for the period of 2001-2014 for six GCC countries provide top performing countries from IPO perspective: Oman and Saudi Arabia (Table 1). The average IPO Market Ratio figures provide a different set of leaders: Qatar, Bahrain and Saudi Arabia. Yearly fluctuations of the IPO market in the GCC region, as well as the uneven performance of the countries, do not allow the calculated average figures for IPOs and IPO values in the region, or the IPO Market Ratio, to give a clear picture of a country's IPO market performance for the studied period. The sum of the shares of the annual IPO Market Ratio for a country within a group for the studied period, provide metrics that can help to compare a country's IPO market activity regardless of the size of its economy or its IPO activity 'waves'.

$R c=\frac{C}{Y} \sum_{y=1}^{Y}\left(\frac{I M R_{c}^{y}}{\sum_{c=1}^{C} I M R_{c}^{y}}\right)$

Where $\mathrm{R}_{\mathrm{c}}=$ the IPO rank of the country $\mathrm{C}$; IMR ${ }_{\mathrm{c}}=$ the IPO Market Ratio (year, country); $C=$ the number of countries in the studied group; and $Y=$ number of years in the studied period. Further normalization provides a percentage of the country's IPO market activity rank. Calculations give three obvious IPO leaders who more often outperformed the regional IPO Market Ratio averages for the 2001-2014 periods, namely: Oman, Qatar, and Saudi Arabia. This provides a view of the IPO leadership within the region other than by size of economy or peak IPO activity; but rather by stable multiyear performances above average for IPO results.

\section{Conclusion}

A lack of available and reliable direct information for this study demanded references from multiple sources and required extensive verification of the data. Despite the close cultural and business connections within the Gulf countries, the study shows different levels of development for GCC economies and stock market investors don't recognise the Gulf countries as a single Gulf area but rather as a collection of separate markets. It is very unlikely that the GCC's financial market could soon grow into a key world market, but it has the potential to become a prominent regional market. The opportunity for development lies in merging the scattered GCC stock exchanges into one powerful stock exchange that covers the whole GCC region. Currently the GCC stock market is more a follower in the international arena and results can be expected only after the world's IPO market recovers from its current stagnation. Nevertheless, the study indicates several points of growth that are based mainly on the quality of IPOs rather than on the size the national economy, and added Bahrain and Oman to the biggest regional economies of Saudi Arabia and the UAE to be considered as possible investment sites. The whole picture could be enhanced by further study into different sources of financing other than IPOs in the region and the stock price dynamics after IPO. The normalized IPO Market Ratio approach introduced in this paper could be studied further and applied to other regions and time periods for study.

\section{References}

Abraham, A, Seyyed, F \& Al-Elg, A 2001, 'Analysis of Diversification Benefits of Investing in the Emerging Gulf Equity Markets', Managerial Finance vol. 27, pp. 47-57.

Ahmed, S \& Alanazi, Liu, B 2013, 'GCC financial and operating performance: evidence from the six countries of the GCC', Griffith University, Brisbane, Queensland, Australia.

Al-Hassan, A, Fernando, D \& Omar, M 2007, 'IPO Behaviour in GCC Countries: Goody-Two Shoes or Bad-to-the-
Bone?', International Monetary Fund, IMF Working Paper, WP/07/149.

Birukov, D 2011, 'Kratkaia Kharakteristika Krupneishikh Arabskikh Fondovykh Rynkov'. Available from: <http://www. iimes.ru/?p=12977>. [30 July 2015].

Birukov, D 2012, 'Obzor Blizhnevostochnykh Fondovykh Rynkov: Janvar 2012'. Available from: <http://www.iimes. $r u / ? p=15758>$. [30 July 2015]. 
Chalhoub Nick \& Hanna, 2015 'An Introduction to the Principa Stock Exchanges of the UAE, Saudi Arabia, Kuwait and Bahrein', By Gibson Dunn\& Crutcher LLT. Available from: http://www.gibsondunn.com/publications/Documents/ Tomlinson-Chalhoub-AnIntrotothePrincipalStockExchangesoft heUAESaudiArabiaKuwaitandBahrain.pdf [30 October 2015].

Deloitte, 2013 'GCC Equity Capital. Markets confidence survey: From a trot to a canter?', p. 16. Available from: <http:// trendsmena.com/wp-content/uploads/2013/11/DeloitteGCC-Equity-2.pdf>. [29 July 2015].

Erb, C, Harvey C \& Viskanta, T 1996, 'Expected Returns and Volatility in 135 countries', Journal of Portfolio Management, 1996, Vol. 22, No. 3: pp. 46-58.

Ernst\&Young 2013, 'Global IPO trends 2012'. Available from: $<$ http://www.ey.com/Publication/vwLUAssets/EY_Broschuere_Working_Capital_Management/\$FILE/2012\%20Year\%20 End\%20Global\%20IPO\%20update.pdf>. [25 November 2015].

Ernst\&Young, 2012, 'Global IPO report 2011'. Available from: <http://drivkraft.ey.se/wp-content/blogs.dir/5/files/2011/06/ Global_IPO_trends-report_2011.pdf>. [15 November 2015].

GCC Stock Markets \& Markets Summary 2015. Available from: $<$ http://www.gulfbase.com>. [2 August 2015].

Gokkent, A, Iradian H \& Anooshah, B 2014, 'GCC: Strong Diversified Growth, Limited Risks', Institute of International Finance, IIF regional overview. Available from: <https://www. iif.com/publication/regional-overview/gcc-strong-diversifiedgrowth-limited-risks> [1 October 2015].

Gukasyan, G 2010, 'Strany SSAPGZv Usloviiakh Ekonomicheskoi Reform (GCC Countries in terms of economic reforms)', Moscow, Novoe Vostocnoe Obozrenie.

Harrathi, N \& Almohaimeed, A 2015, 'Independence between GCC stock market and oil prices and portfolio management strategies under structural breaks', African Journal of Business Management. Vol. 9(5), pp. 233-242.
IPOWatch Europe-Review of the 2009, PricewaterhouseCoopers 2010. Available from: <www.pwc.ru/ru/capital-markets> [2 April 2016].

IPO Watch Europe-Review of the 2010, PricewaterhouseCoopers 2011. Thom Truebridg, Richarn Uiver, p. 32. Available from: $<$ www.pwc.ru/ru/capital-markets> [2 April 2016].

IPOWatch Europe-Review of the 2011, PricewaterhouseCoopers 2012. Richard Uiver, Mark News, Janna Blizeeva, Holger Miss, Philip Suter, Cevin Dezmond, Alex Grey, p. 32. Available from: <www.pwc.ru/ru/capital-markets>. [30 July 2015].

IPOWatch Europe-Review of the 2012, PricewaterhouseCoopers 2013.Thom Troubridg, Richard Uiver, p. 36. Available from: $<$ www.pwc.ru/ru/capital-markets>. [30 July 2015].

IPO Watch Europe I - IIlq. 2014, PricewaterhouseCoopers 2014, p. 29. Available from: www.pwc.pl/rynkikapitalowe [30 July 2015].

IPO Market Watch Q1 2015, PricewaterhouseCoopers 2015. Available from: <www.pwc.ru/ru/capital-markets>. [30 July 2015].

Omran, M \& Gunduz, L 2001, 'Stochastic Trends and Stock Prices in Emerging Markets: the Case of Middle East and North Africa Region', Istanbul Stock Exchange Review vol. 5, pp. 3-16.

Tarbuck, A, Rai, H \& Simpson, O 2014, 'A Vintage Year for Gulf IPOs', Islamic Finance news. [12 November 2014].

Zawya Data Base 2015. Available from: <https://www.zawya. com>. [2 August 2015]. 